\title{
MENINGKATKAN PRESTASI BELAJAR IPS MATERI INTERAKSI SOSIAL MELALUI PENGGUNAAN MODEL PEMBELAJARAN TEAM ASSISTED INDIVIDUALIZATION (TAI)
}

\author{
Juliastuti \\ (Juliastuti SMP Negeri 33 Surabaya, email : mbahtu.33@gmail.com)
}

\begin{abstract}
Abstrak
Berdasarkan hasil observasi dan wawancara dengan guru mata pelajaran IPS di SMPN 33 Surabaya Kota Surabaya, diperoleh bahwa nilai rata-rata penguasaan materi siswa kelas X1 pada materi Interaksi Sosial tahun pelajaran 2012/2013 masih rendah. Aktivitas siswa yang relevan dengan pembelajaran rendah. Salah satu upaya untuk meningkatkan aktivitas siswa dan penguasaan materi Interaksi Sosial adalah dengan menerapkan model pembelajaran kooperatif tipe TAI (Team Asissted Individualization). Tujuan penelitian ini adalah mendeskripsikan penggunaan pembelajaran kooperatif tipe TAI untuk meningkatkan persentase rata-rata : (1) tiap jenis aktivitas siswa; (2) penguasaan materi siswa dari siklus ke siklus. Penelitian ini adalah penelitian tindakan kelas yang dilakukan sebanyak dua siklus. Data penelitian ini terdiri dari data kualitatif, yaitu data aktivitas on task siswa yang diperoleh dari lembar observasi, serta data kuantitatif berupa nilai penguasaan materi interaksi sosial yang diperoleh melalui tes formatif. Hasil penelitian ini menunjukkan bahwa penggunaan model pembelajaran kooperatif tipe memiliki dampak positif dalam meningkatkan prestasi belajar siswa yang ditandai dengan peningkatan ketuntasan belajar siswa dalam setiap siklus, yaitu siklus I 65,63\%, siklus II 100\%
\end{abstract}

Kata Kunci : Team Assisted Individualization (TAI), Prestasi Belajar, IPS

\section{Abstract}

Based on observations and interviews with a social studies teacher at SMPN 33 Surabaya Surabaya, found that the average value of students' mastery of the material in the material class X1 Social Interaction in the academic year 2012/2013 is still low. Activities relevant to the learning of students is low. One effort to increase student activity and mastery of Social Interaction is to implement cooperative learning model type TAI (Team Asissted Individualization). The purpose of this study was to describe the use of cooperative learning TAI to increase the percentage of the average: (1) each type of student activity; (2) The students' mastery of the material from cycle to cycle. This research is a class act who performed three cycles. Data of this study consisted of qualitative data, ie data on the activity of the student task derived from the observation sheets, as well as quantitative data such as the value of social interaction mastery of the material obtained through formative tests. The results of this study indicate that the use of cooperative learning model has a positive impact in improving student achievement marked by increased mastery learning students in each cycle, ie $65.63 \%$ the first cycle, the second cycle of $100 \%$

Keywords: Team Assisted Individualization (TAI), Achievement, IPS

\section{PENDAHULUAN}

Manusia memiliki derajat potensi, latar belakang historis, serta harapan masa depan yang berbeda-beda. Karena adanya perbedaan, manusia dapat silih asah (saling mencerdaskan). Pembelajaran kooperatif secara sadar menciptakan interaksi yang silih asah, sehingga sumber belajar bagi siswa bukan hanya guru dan buku ajar tetapi juga sesama siswa. Manusia adalah makhluk hidup individual, berbeda satu sama lain. Karena sifatnya yang individual, maka manusia yang satu membutuhkan manusia lainnya sehingga sebagai konsekuensi logisnya manusia harus menjadi makhluk sosial, makhluk yang berinteraksi dengan sesamanya. Karena satu sama lain saling membutuhkan maka harus ada interaksi yang silih asih (saling menyayangi satu saling mencintai). Pembelajaran kooperatif merupakan pembelajaran yang 
secara sadar dan sengaja menciptakan interaksi yang saling mengasihi antar sesama siswa.

Pembelajaran IPS tidak lagi mengutamakan pada penyerapan melalui pencapaian informasi, tetapi lebih mengutamakan pada pengembangan kemampuan dan pemrosesan informasi. Untuk itu aktivitas peserta didik perlu ditingkatkan melalui latihan-latihan atau tugas IPS dengan bekerja kelompok kecil dan menjelaskan ide-ide kepada orang lain. (Hartoyo, 2000: 24). Langkah-langkah tersebut memerlukan partisipasi aktif dari siswa. Untuk itu perlu ada metode pembelajaran yang melibatkan siswa secara langsung dalam pembelajaran. Adapun metode yang dimaksud adalah metode pembelajaran kooperatif. Pembelajaran kooperatif adalah suatu pengajaran yang melibatkan siswa bekerja dalam kelompok-kelompok untuk menetapkan tujuan bersama. Felder, (1994: 2). Pembelajaran kooperatif lebih menekankan interaksi antar siswa. Dari sini siswa akan melakukan komunikasi aktif dengan sesama temannya. Dengan komunikasi tersebut diharapkan siswa dapat menguasai materi pelajaran dengan mudah karena "siswa lebih mudah memahami penjelasan dari kawannya dibanding penjelasan dari guru karena taraf pengetahuan serta pemikiran mereka lebih sejalan dan sepadan". (Sulaiman dalam Wahyuni 2001: 2). Penelitian juga menunjukkan bahwa pembelajaran kooperatif memiliki dampak yang amat positif terhadap siswa yang rendah hasil belajarnya. (Nur, 1996: 2). Pete Tschumi dari Universitas Arkansas Little Rock memperkenalkan suatu ilmu pengetahuan pengantar pelajaran komputer selama tiga kali, yang pertama siswa bekerja secara individu, dan dua kali secara kelompok. Dalam kelas pertama hanya 36\% siswa yang mendapat nilai $\mathrm{C}$ atau lebih baik, dan dalam kelas yang bekerja secara kooperatif ada 58\% dan $65 \%$ siswa yang mendapat nilai C atau lebih baik (Felder, 1994:14). Berdasarkan paparan tersebut diatas maka peneliti ingin mencoba melakukan penelitian dengan judul "Upaya Meningkatkan Prestasi Belajar IPS Materi Interaksi Sosial Melalui Penggunaan Model Pembelajaran Team Assisted Individualization ( TAI) Pada Siswa Kelas 7.F SMPN 33 Surabaya"

Berdasarkan latar belakang di atas, maka dapat dirumuskan suatu masalah sebagai berikut: (1) Bagaimanakah peningkatan prestasi belajar siswa dengan diterapkannya metode pembelajaran kooperatif model Team Assisted Individualization pada siswa kelas 7.F SMP Negeri 33 Surabaya, Kota Surabaya semester I tahun pelajaran 2012/2013? (2) Bagaimanakah pengaruh metode pembelajaran kooperatif model Team Assisted Individualization terhadap motivasi belajar siswa kelas 7.F SMP Negeri 33 Surabaya, Kota Surabaya semester I tahun pelajaran 2012/2013?
Sesuai dengan permasalahan di atas, penelitian ini bertujuan untuk: (1) Ingin mengetahui peningkatan prestasi belajar siswa setelah diterapkannya metode pembelajaran kooperatif model Team Assisted Individualization pada siswa kelas 7.F semester I SMP Negeri 33 Surabaya, Kota Surabaya tahun pelajaran 2012/2013. (2) Ingin mengetahui pengaruh motivasi belajar siswa setelah diterapkan metode pembelajaran kooperatif model Team Assisted Individualization pada siswa kelas 7.F SMP Negeri 33 Surabaya, Kota Surabaya semester I tahun pelajaran 2012/2013.

Penelitian ini dapat memberikan manfaat bagi: (1) Sekolah sebagai penentu kebijakan dalam upaya meningkatkan prestasi belajar siswa khususnya pada mata pelajaran IPS materi Interaksi Sosial. (2) Guru, sebagai bahan pertimbangan dalam menentukan metode pembelajaran yang dapat memberikan manfaat bagi siswa. (3) Siswa, dapat meningkatkan motiviasi belajar dan melatih sikap sosial untuk saling peduli terhadap keberhasilan siswa lain dalam mencapai tujuan belajar.

Definisi Operasional Variabel yaitu agar tidak terjadi salah persepsi terhadap judul penelitian ini, maka perlu didefinisikan hal-hal sebagai berikut: (1) Metode pembelajaran kooperatif adalah: Suatu pengajaran yang melibatkan siswa untuk bekerja dalam kelompokkelompok untuk menetapkan tujuan bersama. (2) Motivasi belajar adalah: Suatu proses untuk menggiatkan motif-motif menjadi perbuatan atau tingkah laku untuk memenuhi kebutuhan dan mencapai tujuan, atau keadaan dan kesiapan dalam diri individu yang mendorong tingkah lakunya untuk berbuat sesuatu dalam mencapai tujuan tertentu. (3) Prestasi belajar adalah: Hasil belajar yang dinyatakan dalam bentuk nilai atau dalam bentuk skor, setelah siswa mengikuti pelajaran.

Karena keterbatasan waktu, maka diperlukan pembatasan masalah meliputi: (1) Penelitian ini hanya dikenakan pada siswa kelas 7.F SMP Negeri 33 Surabaya, Kota Surabaya tahun pelajaran 2012/2013. (2) Penelitian ini dilakukan pada bulan Agustus semester ganjil tahun pelajaran 2012/2013. (3) Materi yang disampaikan adalah Interaksi Sosial.

Pembelajaran adalah proses, cara, menjadikan orang atau makhluk hidup belajar. Sedangkan belajar adalah berusaha memperoleh kepandaian atau ilmu, berubah tingka laku atau tanggapan yang disebabkan oleh pengalaman. (KBBI, 1996: 14). Sependapat dengan pernyataan tersebut Sutomo (1993 : 68) mengemukakan bahwa pembelajaran adalah proses pengelolaan lingkungan seseorang yang dengan sengaja dilakukan sehingga memungkinkan dia belajar untuk melakukan atau mempertunjukkan tingkah laku tertentu pula. Sedangkan belajar adalah suatu peoses yang menyebabkan perubahan tingkah laku yang bukan 
disebabkan oleh proses pertumbuhan yang bersifat fisik, tetapi perubahan dalam kebiasaan, kecakapan, bertambah, berkembang daya pikir, sikap dan lain-lain. (Soetomo, 1993 : 120).

Pembelajaran kooperatif adalah suatu pengajaran yang melibatkan siswa untuk bekerja dalam kelompokkelompok untuk menetapkan tujuan bersama. (Felder, 1994 : 2). Wahyuni (2001 : 8) menyebutkan bahwa pembelajaran kooperatif merupakan strategi pembelajaran dengan cara menempatkan siswa dalam kelompokkelompok kecil yang memiliki kemampuan berbeda. Sependapat dengan pernyataan tersebut Setyaningsih (2001: 8) mengemukakan bahwa metode pembelajaran kooperatif memusatkan aktivitas di kelas pada siswa dengan cara pengelompokan siswa untuk bekerjasama dalam proses pembelajaran.

\section{METODE}

Penelitian ini merupakan penelitian tindakan (action research), karena penelitian dilakukan untuk memecahkan masalah pembelajaran di kelas. Penelitian ini juga termasuk penelitian deskriptif, sebab menggambarkan bagaimana suatu teknik pembelajaran diterapkan dan bagaimana hasil yang diinginkan dapat dicapai. Menurut Oja dan Sumarjan (dalam Titik Sugiarti, 1997: 8) mengelompokkan penelitian tindakan menjadi empat macam yaitu, (a) guru sebagai peneliti; (b) penelitian tindakan kolaboratif; (c) simultan terintegratif; (d) administrasi sosial eksperimental. Dalam penelitian tindakan ini menggunakan bentuk guru sebagai peneliti, penanggung jawab penuh penelitian ini adalah guru. Tujuan utama dari penelitian tindakan ini adalah untuk meningkatkan hasil pembelajaran di kelas dimana guru secara penuh terlibat dalam penelitian mulai dari perencanaan, tindakan, pengamatan, dan refleksi. Dalam penelitian ini peneliti tidak bekerjasama dengan siapapun, kehadiran peneliti sebagai guru di kelas sebagai pengajar tetap dan dilakukan seperti biasa, sehingga siswa tidak tahu kalau diteliti. Dengan cara ini diharapkan didapatkan data yang seobjektif mungkin demi kevalidan data yang diperlukan.

Tempat penelitian adalah tempat yang digunakan dalam melakukan penelitian untuk memperoleh data yang diinginkan. Penelitian ini bertempat di SMP Negeri 33 Surabaya, Kota Surabaya tahun pelajaran 2012/2013. Waktu penelitian adalah waktu berlangsungnya penelitian atau saat penelitian ini dilangsungkan. Penelitian ini dilaksanakan pada bulan Oktober semester I, tahun pelajaran 2012/2013. Subyek penelitian adalah siswa-siswi kelas 7.F tahun pelajaran 2012/2013 mapel IPS materi Interaksi Sosial.

Penelitian ini menggunakan Penelitian Tindakan Kelas (PTK). Menurut Tim Pelatih Proyek PGSM, PTK adalah suatu bentuk kajian yang bersifat reflektif oleh pelaku tindakan yang dilakukan untuk meningkatkan kemantapan rasional dari tindakan mereka dalam melaksanakan tugas, memperdalam pemahaman terhadap tindakan-tindakan yang dilakukan itu, serta memperbaiki kondisi dimana praktek pembelajaran tersebut dilakukan (dalam Mukhlis, 2000: 3). Sedangkah menurut Mukhlis (2000: 5) PTK adalah suatu bentuk kajian yang bersifat sistematis reflektif oleh pelaku tindakan untuk memperbaiki kondisi pembelajaran yang dilakukan. Adapun tujuan utama dari PTK adalah untuk memperbaiki/meningkatkan pratek pembelajaran secara berkesinambungan, sedangkan tujuan penyertaannya adalah menumbuhkan budaya meneliti di kalangan guru (Mukhlis, 2000: 5). Sesuai dengan jenis penelitian yang dipilih, yaitu penelitian tindakan, maka penelitian ini menggunakan model penelitian tindakan dari model Lewin yang ditafsirkan oleh Kemmis/

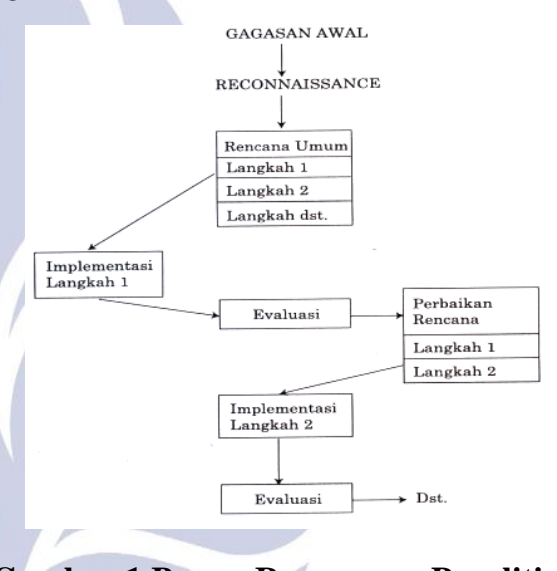

\section{Gambar 1 Bagan Rancangan Penelitian}

Model ini menggambarkan sebuah spiral dari beberapa siklus kegiatan. Bagan yang. melukiskan kegiatan ini pada siklus dasar kegiatan yang terdiri dari mengidentifikasi gagasan umum, melakukan reconnaissance, menyusun rencana umum, mengembangkan langkah tindakan yang pertama, mengimplementasikan langkah tindakan pertama, mengevaluasi, dan Model ini menggambarkan sebuah spiral dari beberapa siklus kegiatan. Bagan yang. melukiskan kegiatan ini pada siklus dasar kegiatan yang terdiri dari mengidentifikasi gagasan umum, melakukan reconnaissance, menyusun rencana umum, mengembangkan langkah tindakan yang pertama, mengimplementasikan langkah tindakan pertama, mengevaluasi, dan memperbaiki rancangan umum. Dari siklus dasar yang pertama inilah, apabila peneliti menilai adanya kesalahan atau kekurangan dapat memperbaiki atau memodifikasi dengan mengembangkannya dalam spiral ke perencanaan langkah tindakan kedua. Apabila dalam implementasinya kemudian dievaluasi masih terdapat kesalahan atau kekurangan, masih bisa diperbaiki atau dimodifikasi, yakni kemudian secara spiral dilanjutkan 
dengan perencanaan tindakan ketiga, dan seterusnya. Siklus dalam spiral ini baru berhenti apabila tindakan substantif yang dilakukan oleh penyaji sudah dievaluasi baik, yaitu penyaji yang mungkin peneliti sendiri atau mitra guru sudah menguasai keterampilan mengajar yang dicobakan dalam penelitian tersebut. Bagi peneliti pengamat atau observer, siklus dihentikan apabila data yang dikumpulkan untuk penelitian sudah jenuh, atau kondisi kelas sudah stabil. Penafsiran yang diberikan oleh Kemmis meliputi halhal berikut.

- Penyusunan gagasan atau rencana umum dapat dilakukan jauh sebelumnya.

- Reconnaissance bukan hanya kegiatan menemukan fakta di lapangan akan tetapi juga mencakup analisis, dan terus berlanjut pada siklus berikutnya, dan bukan hanya pada awal saja.

- Implementasi tindakan bukan pekerjaan yang mudah, karenanya jangan langsung dievaluasi melainkan dimonitor dahulu sampai langkah implementasi dilakukan seoptimal mungkin (Kemmis dalam Elliott, 1991:70).

Instrumen yang digunakan dalam penelitian ini terdiri dari:

1. Silabus

Yaitu seperangkat rencana dan pengaturan tentang kegiatan pembelajaran pengelolahan kelas, serta penilaian hasil belajar.

2. Rencana Pelajaran (RP)

Yaitu merupakan perangkat pembelajaran yang digunakan sebagai pedoman guru dalam mengajar dan disusun untuk tiap putaran. Masing-masing RP berisi kompetensi dasar, indikator pencapaian hasil belajar, tujuan pembelajaran khusus, dan kegiatan belajar mengajar.

3. Lembar Kegiatan Siswa

Lembar kegiatan ini yang dipergunakan siswa untuk membantu proses pengumpulan data hasil eksperimen.

4. Lembar Observasi Kegiatan Belajar Mengajar

a. Lembar observasi pengolahan metode pembelajaran kooperatif model Team Assisted Individualization, untuk mengamati kemampuan guru dalam mengelola pembelajaran.

b. Lembar observasi aktivitas siswa dan guru, untuk mengamati aktivitas siswa dan guru selama proses pembelajaran.

\section{Tes formatif}

Tes ini disusun berdasarkan tujuan pembelajaran yang akan dicapai, digunakan untuk mengukur kemampuan pemahaman materi IPS pada materi Interaksi Sosial.

Data hasil observasi pembelajaran dianalisis bersamasama, kemudian ditafsirkan berdasarkan kajian pustaka dan pengalaman guru. Hasil belajar siswa dianalisis berdasarkan ketuntasan belajar siswa, yaitu 80\% siswa sudah mencapai $65 \%$ taraf penguasaan materi-materi yang diberikan. Uji hipotesa terhadap hipotesa yang dikemukakan pada awal penelitian ini akan diuji dengan menggunakan software SPSS. Data diuji dengan menggunakan statistik non parametrik.

\section{HASIL DAN PEMBAHASAN}

Hasil penelitian ini dapat dikemukakan dalam 2 siklus, pada masing masing siklus dikemukakan hasil penelitian mengenai pelaksanaan metode Team Assisted Individualization, dalam proses belajar IPS untuk materi Interaksi Sosial pada siswa kelas 7.F SMP Negeri 33 Surabaya, Kota Surabaya. Pada akhir proses belajar mengajar siswa diberi tes formatif I dengan tujuan untuk mengetahui tingkat keberhasilan siswa dalam proses belajar mengajar yang telah dilakukan. Adapun data hasil penelitian pada siklus I adalah sebagai berikut:

Tabel 1. Nilai Siswa dalam Siklus 1

\begin{tabular}{|c|c|c|c|c|c|}
\hline \multirow{2}{*}{ No } & \multirow{2}{*}{ Subyek } & \multirow{2}{*}{$\begin{array}{c}\text { Jumlah } \\
\text { Skor } \\
100\end{array}$} & \multirow{2}{*}{ Ketercapaian } & \multicolumn{2}{|c|}{$\begin{array}{c}\text { Ketuntasan } \\
\text { Belajar }\end{array}$} \\
\hline & & & & Belajar & Tidak \\
\hline 1 & DONI AJI & 60 & $60,00 \%$ & & $\sqrt{ }$ \\
\hline 2 & ACHMAD JITARUSTYAWAN & 60 & $60,00 \%$ & & $\sqrt{ }$ \\
\hline 3 & ADELIN NELLA PUTRI & 60 & $60,00 \%$ & $\sqrt{ }$ & \\
\hline 4 & AHADIN INDRA WARDANA & 70 & $70,00 \%$ & & $\sqrt{ }$ \\
\hline 5 & AHMAD DWI CAHYA P & 60 & $60,00 \%$ & $\sqrt{ }$ & \\
\hline 6 & AHMAD SURYA ABDILLAH & 80 & $80,00 \%$ & $\sqrt{ }$ & \\
\hline 7 & AHMAD ZHULFIKAR AKBAR & 80 & $80,00 \%$ & $\sqrt{ }$ & \\
\hline 8 & AKHBAR RIVALDI & 60 & $60,00 \%$ & $\sqrt{ }$ & \\
\hline 9 & ALIFIYA SHALSABILA A. & 70 & $70,00 \%$ & $\sqrt{ }$ & \\
\hline 10 & ANDI WALUYO & 70 & $70,00 \%$ & $\sqrt{ }$ & \\
\hline 11 & ARIE FADILAH PRANOTO & 70 & $70,00 \%$ & $\sqrt{ }$ & \\
\hline 12 & ARIEF RACHMAN GADIR & 60 & $60,00 \%$ & & $\sqrt{ }$ \\
\hline 13 & ARIEF SENO ADJIE & 60 & $60,00 \%$ & $\sqrt{ }$ & \\
\hline 14 & ASHARI MUHAMMAD N & 80 & $80,00 \%$ & $\sqrt{ }$ & \\
\hline 15 & ASMA RUBIAH R. & 60 & $60,00 \%$ & $\sqrt{ }$ & \\
\hline 16 & AULIA KHOIROTUL UMMAH & 60 & $60,00 \%$ & & $\sqrt{ }$ \\
\hline 17 & BETWIN HARIS SUKMA J & 70 & $70,00 \%$ & $\sqrt{ }$ & \\
\hline 18 & CINDY AYU NIRWANA & 70 & $70,00 \%$ & $\sqrt{ }$ & \\
\hline 19 & DANDY INDRA KUSUMA & 80 & $80,00 \%$ & $\sqrt{ }$ & \\
\hline 20 & DANI ADJI SATRIONO & 70 & $70,00 \%$ & & $\sqrt{ }$ \\
\hline 21 & DEA RACHMA SUCITA & 70 & $70,00 \%$ & $\sqrt{ }$ & \\
\hline 22 & DEBY SHINTYA DEWI SARI & 70 & $70,00 \%$ & $\sqrt{ }$ & \\
\hline 23 & EGA FAHRI SETIAWAN & 60 & $60,00 \%$ & & $\sqrt{ }$ \\
\hline 24 & GITA DWI KHAROMAH & 60 & $60,00 \%$ & $\sqrt{ }$ & \\
\hline 25 & IQBAL RAHMANSYAH Y. & 80 & $80,00 \%$ & $\sqrt{ }$ & \\
\hline 26 & LUH PUTU ARDENIA NURITA & 60 & $60,00 \%$ & $\sqrt{ }$ & \\
\hline 27 & MELINDA FITRIA NINGRUM & 70 & $70,00 \%$ & $\sqrt{ }$ & \\
\hline 28 & MOCHAMMAD ZEIN RIZALDI & 60 & $60,00 \%$ & $\sqrt{ }$ & \\
\hline 29 & MUHAMMAD SOLEH & 80 & $80,00 \%$ & $\sqrt{ }$ & \\
\hline 30 & NINDIA PERMATA PUTRI & 70 & $70,00 \%$ & $\sqrt{ }$ & \\
\hline 31 & NUR ANISA PUTRI AMANDA & 70 & $70,00 \%$ & & $\checkmark$ \\
\hline 32 & NURUSYARIFAH KAMALIA & 80 & $80,00 \%$ & $\sqrt{ }$ & \\
\hline 33 & SALSABILLA RIZZA NUR A & 70 & $70,00 \%$ & $\sqrt{ }$ & \\
\hline 34 & SHINTA NURUL FADILAH & 60 & $60,00 \%$ & & v \\
\hline 35 & SILVY NURIYAWATI & 70 & $70,00 \%$ & $\sqrt{ }$ & \\
\hline
\end{tabular}




\begin{tabular}{|c|c|c|c|c|c|}
\hline \multirow{2}{*}{ No } & Subyek & $\begin{array}{c}\text { Jumlah } \\
\text { Skor } \\
\text { 100 }\end{array}$ & & Ketercapaian & \multicolumn{2}{|c|}{$\begin{array}{c}\text { Ketuntasan } \\
\text { Belajar }\end{array}$} \\
\cline { 5 - 6 } & & & & Belajar & Tidak \\
\hline 36 & VIRDHA NAJUBA M. & 70 & $70,00 \%$ & $\checkmark$ & \\
\hline 37 & WIDYA YULIANTI SUPARNO & 80 & $80,00 \%$ & & \\
\hline 38 & WINNA DWI LESTARI & 80 & $80,00 \%$ & & \\
\hline & Jumlah & $\mathbf{2 6 1 0}$ & & & \\
\hline & Nilai rata-rata & $\mathbf{6 8 , 6 8}$ & & & \\
\hline & Nilai tertinggi & $\mathbf{9 0}$ & & & \\
\hline & Nilai terendah & $\mathbf{6 0}$ & & & \\
\hline & Jumlah siswa yang tuntas & $\mathbf{2 6}$ & & & \\
\hline & Jumlah siswa yang tidak tuntas & $\mathbf{1 2}$ & & & \\
\hline & Persentase siswa yang tuntas & $\mathbf{6 8 , 4 2 \%}$ & & & \\
\hline & Persentase siswa yang tidak & & & & \\
\hline & tuntas & $\mathbf{3 1 , 5 8 \%}$ & & & \\
\hline & Daya serap & $\mathbf{6 8 , 6 8 \%}$ & & & \\
\hline
\end{tabular}

Tabel 2. Aktivitas Siswa Pada Pembelajaran Siklus I

\begin{tabular}{|c|c|c|c|}
\hline No & Sikap/Aspek yang dinilai & $\begin{array}{c}\text { Nilai } \\
\text { Kualitatif }\end{array}$ & Nilai Kuantitatif \\
\hline \multicolumn{4}{|c|}{ Penilaian kelompok } \\
\hline 1 & $\begin{array}{c}\text { Menyelesaikan tugas } \\
\text { kelompok dengan baik }\end{array}$ & 70,83 & Baik \\
\hline 2 & Kerjasama kelompok & 70,83 & Baik \\
\hline 3 & Hasil tugas & 69,17 & Cukup \\
\hline \multicolumn{5}{|c|}{ Penilaian Individu Peserta didik } \\
\hline 1. & $\begin{array}{c}\text { Berani mengemukakan } \\
\text { pendapat }\end{array}$ & 69,53 & Cukup \\
\hline 2. & $\begin{array}{c}\text { Berani menjawab } \\
\text { pertanyaan }\end{array}$ & 73,44 & Baik \\
\hline 3. & Inisiatif & 71,88 & Baik \\
\hline 4. & Ketelitian & 73,44 & Baik \\
\hline
\end{tabular}

Dari tabel di atas dapat dijelaskan bahwa dengan menerapkan metode pembelajaran kooperatif model Team Assisted Individualization diperoleh nilai rata-rata prestasi belajar siswa pada siklus I adalah 69,06 dan ketuntasan belajar mencapai $65,63 \%$ atau ada 21 siswa dari 38 siswa sudah tuntas belajar. Hasil tersebut menunjukkan bahwa pada siklus pertama secara klasikal siswa belum tuntas belajar, karena siswa yang memperoleh nilai $\geq 65$ hanya sebesar $65 \%$ lebih kecil dari persentase ketuntasan yang dikehendaki yaitu sebesar $85 \%$. Hal ini disebabkan karena siswa masih merasa baru dan belum mengerti apa yang dimaksudkan dan digunakan guru dengan menerapkan metode pembelajaran kooperatif model Team Assisted Individualization.

Tabel 3 Aktivitas Guru Pada Pembelajaran Siklus I

\begin{tabular}{|c|c|c|c|}
\hline NO & $\begin{array}{c}\text { KEGIATAN } \\
\text { GURU }\end{array}$ & SKOR & PERSENTASE \\
\hline 1 & $\begin{array}{c}\text { Kegiatan } \\
\text { Pendahuluan }\end{array}$ & 10 & $\mathbf{6 2 , 5 0}$ \\
\hline 2 & Kegiatan Inti & 21 & $\mathbf{7 5 , 0 0}$ \\
\hline 3 & Kegiatan Penutup & 4 & $\mathbf{5 0 , 0 0}$ \\
\hline & JUMLAH & $\mathbf{3 5}$ & $\mathbf{1 8 7 , 5}$ \\
\hline \multicolumn{2}{|c|}{ RATA2 } & $\mathbf{1 1 , 6 7}$ & $\mathbf{6 2 , 5 0}$ \\
\hline \multicolumn{2}{|c}{ KRITERIA } & \multicolumn{2}{c}{ Kurang } \\
\hline
\end{tabular}

Berdasarkan tabel data aktivitas guru pada proses pembelajaran diketahui bahwa tindakan guru paling dominan terdapat pada pelaksanaan kegiatan inti memperoleh skor 21 dengan persentase $75,00 \%$, sedangkan aktivitas yang kurang terdapat pada pelaksanaan kegiatan penutup diperoleh skor 4 dengan persentase $50,00 \%$.

Dalam pelaksanaan kegiatan belajar mengajar diperoleh informasi dari hasil pengamatan sebagai berikut: (1) Guru kurang baik dalam memotivasi siswa dan dalam menyampaikan tujuan pembelajaran (2) Guru kurang baik dalam pengelolaan waktu (3) Siswa kurang begitu antusias selama pembelajaran berlangsung.

Pelaksanaan kegiatan belajar mengajar pada siklus I ini masih terdapat kekurangan, sehingga perlu adanya revisi untuk dilakukan pada siklus berikutnya. (1) Guru perlu lebih terampil dalam memotivasi siswa dan lebih jelas dalam menyampaikan tujuan pembelajaran. Dimana siswa diajak untuk terlibat langsung dalam setiap kegiatan yang akan dilakukan. (2) Guru perlu mendistribusikan waktu secara baik dengan menambahkan informasi-informasi yang dirasa perlu dan memberi catatan (3) Guru harus lebih terampil dan bersemangat dalam memotivasi siswa sehingga siswa bisa lebih antusias.

Pada akhir proses belajar mengajar siswa diberi tes formatif II dengan tujuan untuk mengetahui tingkat keberhasilan siswa dalam proses belajar mengajar yang telah dilakukan. Instrumen yang digunakan adalah tes formatif II. Adapun data hasil penelitian pada siklus II adalah sebagai berikut:

Tabel 4. Nilai Siswa dalam Siklus 2

\begin{tabular}{|c|c|c|c|c|c|}
\hline \multirow{3}{*}{ No } & \multirow{3}{*}{ Subyek } & \multirow{3}{*}{$\begin{array}{c}\text { Jumlah } \\
\text { Skor } \\
100\end{array}$} & \multirow{3}{*}{ Ketercapaian } & \multirow{2}{*}{\multicolumn{2}{|c|}{$\begin{array}{c}\text { Ketuntasan } \\
\text { Belajar }\end{array}$}} \\
\hline & & & & & \\
\hline & & & & $\mathbf{Y a}$ & Tidak \\
\hline 1 & DONI AJI & 70 & $70,00 \%$ & $\sqrt{ }$ & \\
\hline 2 & ACHMAD JITARUSTYAWAN & 80 & $80,00 \%$ & $\sqrt{ }$ & \\
\hline 3 & ADELIN NELLA PUTRI & 70 & $70,00 \%$ & $\sqrt{ }$ & \\
\hline 4 & AHADIN INDRA WARDANA & 80 & $80,00 \%$ & $\sqrt{ }$ & \\
\hline 5 & AHMAD DWI CAHYA P & 80 & $80,00 \%$ & $\sqrt{ }$ & \\
\hline 6 & AHMAD SURYA ABDILLAH & 80 & $80,00 \%$ & $\sqrt{ }$ & \\
\hline 7 & AHMAD ZHULFIKAR AKBAR & 90 & $90,00 \%$ & $\sqrt{ }$ & \\
\hline 8 & AKHBAR RIVALDI & 70 & $70,00 \%$ & $\sqrt{ }$ & \\
\hline 9 & ALIFIYA SHALSABILA ARJUN & 70 & $70,00 \%$ & $\sqrt{ }$ & \\
\hline 10 & ANDI WALUYO & 70 & $70,00 \%$ & $\sqrt{ }$ & \\
\hline 11 & ARIE FADILAH PRANOTO & 70 & $70,00 \%$ & $\sqrt{ }$ & \\
\hline 12 & ARIEF RACHMAN GADIR & 80 & $80,00 \%$ & $\sqrt{ }$ & \\
\hline 13 & ARIEF SENO ADJIE & 90 & $90,00 \%$ & $\sqrt{ }$ & \\
\hline 14 & ASHARI MUHAMMAD N & 80 & $80,00 \%$ & $\sqrt{ }$ & \\
\hline 15 & ASMA RUBIAH R. & 90 & $90,00 \%$ & $\sqrt{ }$ & \\
\hline 16 & AULIA KHOIROTUL UMMAH & 80 & $80,00 \%$ & $\sqrt{ }$ & \\
\hline 17 & BETWIN HARIS SUKMA J & 70 & $70,00 \%$ & $\sqrt{ }$ & \\
\hline 18 & CINDY AYU NIRWANA & 70 & $70,00 \%$ & $\sqrt{ }$ & \\
\hline 19 & DANDY INDRA KUSUMA & 80 & $80,00 \%$ & $\sqrt{ }$ & \\
\hline 20 & DANI ADJI SATRIONO & 70 & $70,00 \%$ & $\sqrt{ }$ & \\
\hline 21 & DEA RACHMA SUCITA & 70 & $70,00 \%$ & $\sqrt{ }$ & \\
\hline 22 & DEBY SHINTYA DEWI SARI & 70 & $70,00 \%$ & $\sqrt{ }$ & \\
\hline 23 & EGA FAHRI SETIAWAN & 80 & $80,00 \%$ & $\sqrt{ }$ & \\
\hline 24 & GITA DWI KHAROMAH & 90 & $90,00 \%$ & $\sqrt{ }$ & \\
\hline 25 & IQBAL RAHMANSYAH Y. & 80 & $80,00 \%$ & $\sqrt{ }$ & \\
\hline 26 & LUH PUTU ARDENIA NURITA & 90 & $90,00 \%$ & $\sqrt{ }$ & \\
\hline 27 & MELINDA FITRIA NINGRUM & 70 & $70,00 \%$ & $\sqrt{ }$ & \\
\hline 28 & MOCHAMMAD ZEIN RIZALDI & 70 & $70,00 \%$ & $\sqrt{ }$ & \\
\hline
\end{tabular}




\begin{tabular}{|c|c|c|c|c|c|}
\hline \multirow{3}{*}{ No } & \multirow{3}{*}{ Subyek } & \multirow{3}{*}{$\begin{array}{c}\text { Jumlah } \\
\text { Skor } \\
100\end{array}$} & \multirow{3}{*}{ Ketercapaian } & \multirow{2}{*}{\multicolumn{2}{|c|}{$\begin{array}{c}\text { Ketuntasan } \\
\text { Belajar }\end{array}$}} \\
\hline & & & & & \\
\hline & & & & Ya & Tidak \\
\hline 29 & MUHAMMAD SOLEH & 80 & $80,00 \%$ & $\sqrt{ }$ & \\
\hline 30 & NINDIA PERMATA PUTRI & 90 & $90,00 \%$ & $\sqrt{ }$ & \\
\hline 31 & NUR ANISA PUTRI AMANDA & 90 & $90,00 \%$ & $\sqrt{ }$ & \\
\hline 32 & NURUSYARIFAH KAMALIA & 80 & $80,00 \%$ & $\sqrt{ }$ & \\
\hline 33 & SALSABILLA RIZZA NUR A & 70 & $70,00 \%$ & $\sqrt{ }$ & \\
\hline 34 & SHINTA NURUL FADILAH & 70 & $70,00 \%$ & $\sqrt{ }$ & \\
\hline 35 & SILVY NURIYAWATI & 80 & $80,00 \%$ & $\sqrt{ }$ & \\
\hline 36 & VIRDHA NAJUBA M. & 90 & $90,00 \%$ & $\sqrt{ }$ & \\
\hline 37 & WIDYA YULIANTI SUPARNO & 90 & $90,00 \%$ & & \\
\hline \multirow[t]{10}{*}{38} & WINNA DWI LESTARI & 80 & $80,00 \%$ & & \\
\hline & Jumlah & 2980 & & & \\
\hline & Nilai rata-rata & $\mathbf{7 8 , 4 2}$ & & & \\
\hline & Nilai tertinggi & 100 & & & \\
\hline & Nilai terendah & 70 & & & \\
\hline & Jumlah siswa yang tuntas & 38 & & & \\
\hline & Jumlah siswa yang tidak tuntas & $\mathbf{0}$ & & & \\
\hline & Persentase siswa yang tuntas & $100,00 \%$ & & & \\
\hline & $\begin{array}{c}\text { Persentase siswa yang tidak } \\
\text { tuntas }\end{array}$ & $0,00 \%$ & & & \\
\hline & Daya serap & $78,42 \%$ & & & \\
\hline
\end{tabular}

Dari tabel di atas, tanpak aspek-aspek yang diamati pada kegiatan belajar mengajar (siklus II) yang dilaksanakan oleh guru dengan menerapkan metode pembelajaran kooperatif model Team Assisted Individualization mendapatkan penilaian yang cukup baik dari pengamat. Maksudnya dari seluruh penilaian tidak terdapat nilai kurang. Namun demikian penilaian tesebut belum merupakan hasil yang optimal, untuk itu ada beberapa aspek yang perlu mendapatkan perhatian untuk penyempurnaan penerapan pembelajaran selanjutnya. Aspek-aspek tersebut adalah memotivasi siswa, membimbing siswa merumuskan kesimpulan/menemukan materi, dan pengelolaan waktu.

Dengan penyempurnaan aspek-aspek I atas alam penerapan metode pembelajarn kooperatif model Team Assisted Individualization diharapkan siswa dapat menyimpulkan apa yang telah mereka pelajari dan mengemukakan pendapatnya sehingga mereka akan lebih memahami tentang apa yang telah mereka lakukan. Berikut disajikan hasil observasi akivitas siswa pada siklus II :

Tabel 5 Aktivitas Siswa Pada Pembelajaran Siklus II

\begin{tabular}{|c|l|c|c|}
\hline No & \multicolumn{1}{|c|}{$\begin{array}{c}\text { Sikap/Aspek yang } \\
\text { dinilai }\end{array}$} & $\begin{array}{c}\text { Nilai } \\
\text { Kualitatif }\end{array}$ & $\begin{array}{c}\text { Nilai } \\
\text { Kuantitatif }\end{array}$ \\
\hline \multicolumn{4}{|c|}{ Penilaian kelompok } \\
\hline 1 & $\begin{array}{l}\text { Menyelesaikan tugas } \\
\text { kelompok dengan baik }\end{array}$ & 85 & Memuaskan \\
\hline 2 & Kerjasama kelompok & 86,67 & Memuaskan \\
\hline 3 & Hasil tugas & 88,33 & Memuaskan \\
\hline \multicolumn{4}{|c|}{ Penilaian Individu Peserta didik } \\
\hline 1. & $\begin{array}{l}\text { Berani mengemukakan } \\
\text { pendapat }\end{array}$ & 95,31 & Memuaskan \\
\hline
\end{tabular}

\begin{tabular}{|c|l|c|c|}
\hline No & \multicolumn{1}{|c|}{$\begin{array}{c}\text { Sikap/Aspek yang } \\
\text { dinilai }\end{array}$} & $\begin{array}{c}\text { Nilai } \\
\text { Kualitatif }\end{array}$ & $\begin{array}{c}\text { Nilai } \\
\text { Kuantitatif }\end{array}$ \\
\hline 2. & $\begin{array}{l}\text { Berani menjawab } \\
\text { pertanyaan }\end{array}$ & 96,88 & Memuaskan \\
\hline 3. & Inisiatif & 95,31 & Memuaskan \\
\hline 4. & Ketelitian & 97,66 & Memuaskan \\
\hline
\end{tabular}

Aktivitas siswa yang paling dominan pada siklus II adalah berani menjawab pertanyaan yaitu skor 96,88 dengan kriteria memuaskan. Aktivitas lain juga mengalami peningkatan dari siklus I yaitu pada aspek berani mengemukakan pendapat memperoleh skor 95,31 dengan kriteria memuaskan, sedangkan pada aspek mengemukakan inisiatif skor 95,31 dengan kriteria memuaskan.

Dari tabel hasil tes formatif siklus II di atas diperoleh nilai rata-rata prestasi belajar siswa adalah 78,13 dan ketuntasan belajar mencapai $100 \%$ atau ada 38 siswa dari 38 siswa sudah tuntas belajar. Hasil ini menunjukkan bahwa pada siklus II ini ketuntasan belajar secara klasikal telah mengalami peningkatan sedikit lebih baik dari siklus I. Adanya peningkatan hasil belajar siswa ini karena setelah guru menginformasikan bahwa setiap akhir pelajaran akan selalu diadakan tes sehingga pada pertemuan berikutnya siswa lebih termotivasi utnuk belajar. Selain itu siswa juga sudah mulai mengerti apa yang dimaksudkan dan dinginkan guru dengan menerapkan metode pembelajaran kooperatif model Team Assisted Individualization.

Tabel 6.Aktivitas Guru Pada Pembelajaran Siklus II

\begin{tabular}{|c|c|c|c|}
\hline No & $\begin{array}{c}\text { Kegiatan } \\
\text { Guru }\end{array}$ & Skor & Nilai \\
\hline 1 & $\begin{array}{c}\text { Kegiatan } \\
\text { Pendahuluan }\end{array}$ & 15 & $\mathbf{9 3 , 7 5}$ \\
\hline 2 & $\begin{array}{c}\text { Kegiatan } \\
\text { Inti }\end{array}$ & 27 & $\mathbf{9 6 , 4 3}$ \\
\hline 3 & $\begin{array}{c}\text { Kegiatan } \\
\text { Penutup }\end{array}$ & 7 & $\mathbf{8 7 , 5 0}$ \\
\hline JUMLAH & 49 & $\mathbf{2 7 7 , 6 8}$ \\
\hline KRATA2 & $\mathbf{1 6 , 3 3}$ & $\mathbf{9 2 , 5 6}$ \\
\hline KRITERIA & \multicolumn{2}{|c|}{ Sangat Baik } \\
\hline
\end{tabular}

Berdasarkan tabel data aktivitas guru pada proses pembelajaran diketahui bahwa tindakan guru paling dominan terdapat pada pelaksanaan kegiatan inti memperoleh skor 27 dengan persentase 96,43\%, sedangkan aktivitas yang kurang terdapat pada pelaksanaan kegiatan penutup diperoleh skor 7 dengan persentase $87,50 \%$. 
Pembahasan (1) Ketuntasan Hasil belajar Siswa : Melalui hasil penelitian ini menunjukkan bahwa metode pembelajaran kooperatif model Team Assisted Individualization memiliki dampak positif dalam meningkatkan prestasi belajar siswa. Hal ini dapat dilihat dari semakin mantapnya pemahaman siswa terhadap materi yang disampaikan guru (ketuntasan belajar meningkat dari siklus I dan II) yaitu masing-masing $68.42 \%$ dan $100 \%$. Pada siklus II ketuntasan belajar siswa secara klasikal telah tercapai. (2) Kemampuan Guru dalam Mengelola Pembelajaran : Berdasarkan analisis data, diperoleh aktivitas siswa dalam proses metode pembelajaran kooperatif model Team Assisted Individualization dalam setiap siklus mengalami peningkatan. Hal ini berdampak positif terhadap prestasi belajar siswa yaitu dapat ditunjukkan dengan meningkatnya nilai rata-rata siswa pada setiap siklus yang terus mengalami peningkatan. (3) Aktivitas Guru dan Siswa Dalam Pembelajaran : Berdasarkan analisis data, diperoleh aktivitas siswa dalam proses pembelajaran IPS pada materi Interaksi Sosial dengan metode pembelajaran kooperatif model Team Assisted Individualization yang paling dominan adalah bekerja dengan menggunakan alat/media, mendengarkan/memperhatikan penjelasan guru, dan diskusi antar siswa/antara siswa dengan guru. Jadi dapat dikatakan bahwa aktivitas isiswa dapat dikategorikan aktif. Sedangkan untuk aktivitas guru selama pembelajaran telah melaksanakan langkah-langkah metode pembelajaran kooperatif model Team Assisted Individualization dengan baik. Hal ini terlihat dari aktivitas guru yang muncul di antaranya aktivitas membimbing dan mengamati siswa dalam mengerjakan kegiatan LKS / menemukan materi, menjelaskan materi yang sulit, memberi umpan balik/evaluasi/tanya jawab dimana prosentase untuk aktivitas di atas cukup besar.

\section{PENUTUP \\ Simpulan}

Penelitian tindakan kelas tentang peningkatan prestasi/nilai peserta didik mata pelajaran IPS topik produktifitas melalui teknik tes unjuk kerja telah dilaksanakan dalam dua siklus kegiatan, menghasilkan kesimpulan, (1) Melalui teknik tes unjuk kerja, dapat meningkatkan kemampuan peserta didik dalam menguasai mata pelajaran IPS, topik produktifitas, (2) Prestasi peserta didik setelah mengalami 2 siklus tetap tinggi, walaupun dilakukan perubahan spesialisasi kerja, serta merubah skor dari hasil produksi dibagi 2 menjadi hasil produksi dibagi 4 pada putaran 3 siklus II. Siklus I ratarata nilai peserta didik 72,95 , sedangkan pada siklus II rata-rata 79,21 , ada kenaikan senilai 6,26 atau $8,58 \%$ berarti terjadi peningkatan prestasi/nilai diatas siklus I, (3) Faktor-faktor yang mempengaruhi pelaksanaan pembelajaran dalam rangka peningkatan kemampuan peserta didik pada topik produktifitas adalah: (a) Faktor peserta didik: Ada peserta didik yang tidak mempersiapkan lebih dahulu bahan yang harus dibawanya, tetapi meminta kepada peserta didik yang lain sehingga mempengaruhi nilai skor yang diterimanya, ada rasa setia kawan diantara peserta didik sehingga membantu teman dalam memotong kertas dan menulis nomor halaman serta memberi judul pada cover, kurangnya kecepatan dalam membuat buku tulis, karena masih ada buku tulis yang tidak layak jual. (b) Faktor guru: Dituntut kecepatan dan ketelitian dalam mensortir buku tulis hasil produksi, dituntut mampu mengawasi kegiatan setiap putaran baik putaran 1, 2 dan 3 dari 38 peserta didk dalam waktu bersamaan dan runtut, (c) Faktor waktu: Kurangnya waktu. Sehingga pada saat menjelaskan konsep produktifitas dilakukan dengan tergesa-gesa, supaya waktu yang tersisa cukup untuk praktek membuat buku, (4) Hipotesa teknik tes unjuk kerja dapat meningkatkan prestasi/ nilai peserta didik mata pelajaran IPS topik produktifitas dapat diterima.

\section{Saran}

Dari hasil kegiatan pembelajaran yang telah dilakukan selama tiga siklus, dan berdasarkan seluruh pembahasan serta analisis yang telah dilakukan dapat disimpulkan sebagai berikut: (1) Pembelajaran dengan kooperatif model Team Assisted Individualization memiliki dampak positif dalam meningkatkan prestasi belajar siswa yang ditandai dengan peningkatan ketuntasan belajar siswa dalam setiap siklus, yaitu siklus I $68.42 \%$, siklus II 100\%. (2) Penerapan metode pembelajaran kooperatif model Team Assisted Individualization mempunyai pengaruh positif, yaitu dapat meningkatkan motivasi belajar siswa yang ditunjukan dengan hasil wawancara dengan beberapa siswa, rata-rata jawaban siswa menyatakan bahwa mereka tertarik dan berminat dengn metode pembelajaran kooperatif model Team Assisted Individualization sehingga mereka menjadi termotivasi untuk belajar.

Dari hasil penelitian yang diperoleh dari uraian sebelumnya agar proses belajar mengajar IPS lebih efektif dan lebih memberikan hasil yang optimal bagi siswa, maka disampaikan saran sebagai berikut: (1) Untuk melaksanakan metode pembelajaran kooperatif model Team Assisted Individualization memerlukan persiapan yang cukup matang, sehingga guru harus mampu menentukan atau memilih topik yang benar-benar bisa diterapkan dengan model kooperatif model Team Assisted Individualization dalam proses belajar mengajar sehingga diperoleh hasil yang optimal. (2) Dalam rangka 
meningkatkan prestasi belajar siswa, guru hendaknya lebih sering melatih siswa dengan berbagai metode pembelajaran, walau dalam taraf yang sederhana, dimana siswa nantinya dapat menemukan pengetahuan baru, memperoleh materi dan keterampilan, sehingga siswa berhasil atau mampu memecahkan masalah-masalah yang dihadapinya. (3) Perlu adanya penelitian yang lebih lanjut, karena hasil penelitian ini hanya dilakukan di SMP Negeri 33 Surabaya, Kota Surabaya tahun pelajaran 2012/2013. (4) Untuk penelitian yang serupa hendaknya dilakukan perbaikan-perbaikan agar diperoleh hasil yang lebih baik.

\section{DAFTAR PUSTAKA}

Felder, Richard M. 1994. Cooperative Learning in Technical Corse, (online), (PcllldMMy \% DocumentlCoop \% 20 Report

KBBI. 1996. Edisi Kedua. Jakarta: Balai Pustaka

Kemmis, S. dan Mc. Taggart, R. 1988. The Action Research Planner. Victoria Dearcin University Press.

Nur, Muhammad. 1996. Pembelajaran Kooperatif. Surabaya. Universitas Negeri Surabaya.

Soetomo. 1993. Dasar-dasar Interaksi Belajar Mengajar. Surabaya Usaha Nasional.

Wahyuni, Dwi. 2001. Studi Tentang Pembelajaran Kooperatif Terhadap Hasil Belajar IPS. Malang: Program Sarjana Universitas Negeri Malang.

Wahyuni, Dwi. 2001. Studi Tentang Pembelajaran Kooperatif Terhadap Hasil Belajar IPS. Malang: Program Sarjana Universitas Negeri Malang.

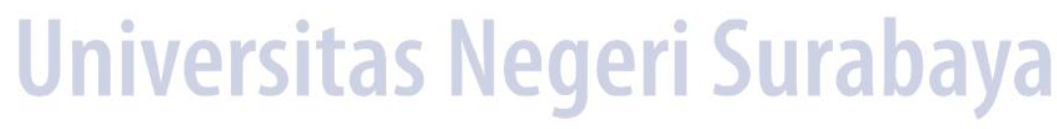

